\title{
THE EFFECT OF FINANCIAL PERFORMANCE ON STOCK RETURN AT MANUFACTURING COMPANY OF INDONESIA STOCK EXCHANGE
}

\author{
Juniarta I Wayan*, Purbawangsa Ida Bagus Anom \\ Faculty of Economics and Business, University of Udayana, Bali, Indonesia \\ *E-mail: kayan.juniarta@gmail.com
}

\begin{abstract}
The purpose of this study is to find out the effect of return on investment, earning per share, operational cash flow, economic value added, and market value added towards the stock return at manufacturing companies in Indonesia Stock Exchange. The population of this study was the all manufacturing industry registered at Indonesia Stock Exchange which was studied from 2005 to 2011. The method used to determine samples was using purposive sampling method with some fixed criteria with the total number of 11 samples of manufacture companies. The data used was secondary data which was obtained Indonesia Stock Exchange (www.idx.co.id) and also from Indonesia Capital Market Directory from 2005 up to 2010. To answer the problems of the study and to test the research hypothesis, multiple regression was used together with the application of Statistical Product and Service Solutions (SPSS). The result of this study shows that 1) Return on investment has insignificant influence towards stock return, 2) Earning per share insignificant influence towards stock return, 3) Operational cash flow has a negative and significant influence towards stock return, 4) EVA has a positive and significant influence towards stock, 5) MVA has insignificant influence towards stock. The result showed that the Economic value added and Operational cash flow has a significant towards stock return. Therefore, Economic value added and Operational cash flow should be become consideration substance for investor in making stock investment decision. The insignificant of Return on investment, Earning per share, and Market value added towards stock return, can be a suggestion to do more research with longer duration of observation and also included all sectors in Indonesia Stock Exchange.
\end{abstract}

\section{KEY WORDS}

Return on investment, earning per share, operational cash flow, economic value added, market value added, stock return.

The motivation of investors to make investment decisions is to maximize the level of profit. For investors or owners of capital, the level of profit or return is certainly an important indicator in an effort to increase prosperity. Fahmi (2013) defines returns as profits obtained by companies, individuals, and institutions from the results of their investment policies, while Trisnawati and Wahidahwati (2013) define returns as profits obtained through share ownership over a certain period of time. Return in investment activities is inseparable with regard to risk factors, this is because the owners of capital or investors always expect an appropriate level of return on each investment risk they face. Risk is the possibility that the level of output is not as expected (Sartono, 2008). The attitude of investors to risk will certainly depend on the preferences they expect of the risk. Investors classified as riskaverse or risk seekers will choose a higher investment risk that is accompanied by expectations of a high level of profit as well, conversely if investors are classified as avoiding risk or risk averter certainly cannot expect more from the level of profit they will receive. Thus, the relationship between return and risk is positive and linear (Tandelilin, 2001).

According to Hartono (2008), to determine the value of a stock there are two kinds of analysis, including; fundamental analysis and technical analysis. Fundamental analysis or company analysis essentially will use historical data from the company on its financial strength. Ang (1997) revealed, a fundamental analysis based on the belief that the value of a stock is strongly influenced by the performance of the company that issued the stock, 
meaning that if the prospect of a public company is very strong and good, then the stock price is expected to reflect these strengths and the price will increase. earnings by the company have information content for the stock market, where the strength of earnings will be reflected in changes in price and trading volume of shares, and is a signal expected by investors (Donton and Ronen, 1993; in Sari, 2007). Several empirical studies examining market reaction to company earnings announcements have been widely publicized, one of which is by Beaver and Duker (1972) in Sukartha (2007) which states that changes in security prices in the capital market generally have a higher relationship with changes in earnings. rather than changes in cash flow.

Research by Meythi and Hartono (2012) on the Indonesia Stock Exchange concluded that earnings information had a more significant effect on increasing stock returns than other financial performance, while Qodriyah (2012) in his study of manufacturing companies revealed that, in the corporate cycle, especially at the beginning the up stage and the maturity stage, earnings information can be used to measure a company's performance, and have a value relevant to market equity. The ability of companies to generate profits in fundamental analysis can be assessed by several indicators, including earning per share and return on investment. Return on investment or often also referred to as return on assets shows how efficiently a company uses its assets to generate profits, while earnings per share are derived from the amount of profit divided by the number of outstanding shares (Wira, 2011). Sudiyatno and Suharmanto (2011), and Zuliarni (2012) in their respective studies concluded that there was a real effect of return on assets on stock returns. Likewise, studies by Priatinah and Kusuma (2012) which show that, return on investment has a positive and significant effect on stock returns, while Sunardi (2010), Heriani (2011), and Hatta and Dwiyanto (2012) reveal the opposite, ROI or ROA has not a significant positive effect. Harjito and Aryayoga (2009), Setiyorini (2011), and Arista and Astohar (2012) found different results, the performance of return on assets in their respective studies actually did not significantly influence stock returns.

Research to determine the response of market participants to the publication of earnings per share was conducted by Susetyo (2013) in food and beverage sub-sector companies. Based on observations during the period 2007 to 2010, the results show that earning per share information or earnings per share can be used as a reference in predicting the high and low stock prices. Susetyo's (2013) findings support several previous studies, such as; Pradhono and Christiawan (2004), Dimitros et al. (2006), Nurfadillah (2011), Seetharaman and Raj (2011), Priatinah and Kusuma (2012), and Hatta and Dwiyanto (2012). Research with different results was revealed by Setiyorini (2011), Tiswiyanti (2011), Arista and Astohar (2012), and Rahmadi (2013) who concluded that earnings per share had a nonsignificant negative effect on stock returns.

Analysis of earnings in investment valuation is very basic, however estimation of company's cash flow is also very essential. Cash flow as well as profit is a component in determining the value of the company (Hartono, 2008). The greater the positive cash flow generated, the more liquid and large internal company funds, with company liquidity will affect the assessment of company performance and of course will ultimately increase the value of the company (Pike and Dobbins, 1986; in Benardi, 2010).

Based on the time dimension, the company's cash flow can be grouped into three activities, including; investment activities, operating activities, and funding activities. Puspitasari (2010) said, the estimation of operating cash flow would be very important in achieving an optimal company value. Operating cash flow will not experience distortion compared to net profit figures (Setiyorini, 2011). (Subramanyam and Wild, 2010; in Nany, 2013) argues, operating activities are the main source of company profits that show success in carrying out its operational activities effectively.

Pangemanan and Budiarso (2011) and Setiyorini (2011) concluded that, operating cash flow is a financial indicator that has a positive and significant effect on stock returns, but research by Tiswiyanti (2011), and Meythi and Hartono (2012), in fact indicate the opposite results. Qodriyah (2012) in his research on manufacturing companies revealed that, at the growth stage, operating cash flow turned out to have more relevance to market values than 
earnings indicators, while Rahmadi (2013) argued that, an increase in operating cash flow was directly proportional to the increase stock returns. Trisnawati and Wahidawati (2013) in their research also showed a positive relationship between operating cash flow and stock returns. Utomo (1999) said, the company's goals to maximize profits are less relevant, the appropriate goal is to maximize value, so that more accurate and reliable performance measurement procedures are needed that can encourage company activities to tend to add value. Economic value added (EVA) and market value added (MVA) indicate the existence of value creation from an investment (Wiagustini, 2014). Economic value added measures the added value produced by a company by reducing the cost of capital that arises as a result of investments that have been made, while the market value added is a cumulative measure that shows how much added value to the capital invested by investors.

Several studies that examine the relationship of EVA to stock returns, among others; (Lehn et al., 1996; in Iriana, 2003), Worthington and West (2004), Idamiharti (2010), and Turangan and Wijaya (2015) which concluded that EVA performance had a positive and significant effect on stock prices and returns. Surveys by Pradhono and Christiawan (2004), Tiswiyanthi (2011), Sudiyatno and Suharmanto (2011), and Rahayu and Aisjah (2012) revealed that EVA provides a positive but not significant effect on stock returns. Different results were revealed by Heriani (2011), Setiyorini (2011), Susetyo (2013), and Rahmadi (2013) who concluded that economic value added had a negative and not significant effect on stock returns.

Research by Heriani (2011) and Rahayu and Aisjah (2012) provides the fact that, market value added has an insignificant negative effect on stock returns, while Rahmadi (2013) shows the opposite results, market value added has a positive effect, but not significantly on return stock. Different studies published by Sasongko et al. (2013). Other research by Turangan and Wijaya (2015) concludes that, market value added is a positive and significant predictor of the company's stock price.The main characteristic of the manufacturing industry is processing resources into finished goods through a manufacturing process. Products produced by the manufacturing industry today include several types of businesses, including basic and chemical industries, consumer goods industries and miscellaneous industries. Manufacturing industry will at least make a positive contribution to three things, including; gross domestic product (GDP), foreign exchange reserves, and the opening of new jobs. Bank Indonesia data as quoted by Indonesia Finance Today (2012) states, during the period 2003 to 2011 the contribution of the manufacturing industry to gross domestic product showed a fluctuating value with a tendency to decline.

Hypotheses:

- $\mathrm{H}_{1}$ : Return on investment has a significant positive effect on stock returns on manufacturing industry companies on the Indonesia Stock Exchange;

- $\mathrm{H}_{2}$ : Earning per share has a significant positive effect on stock returns of manufacturing industry companies on the Indonesia Stock Exchange;

- $\mathrm{H}_{3}$ : Operating cash flow has a significant positive effect on stock returns on manufacturing industry companies on the Indonesia Stock Exchange;

- $\mathrm{H}_{4}$ : Economic value added has a significant positive effect on stock returns on manufacturing industry companies on the Indonesia Stock Exchange;

- $\mathrm{H}_{5}$ : Market value added has a significant positive effect on stock returns on manufacturing industry companies on the Indonesia Stock Exchange.

\section{METHODS OF RESEARCH}

This study was designed as an explanatory research, namely research that explains how the influence of financial performance is proxied as return on investment, earnings per share, operating cash flow, economic value added, and market value added to stock returns. The data in this study are quantitative data. Testing data in this study is to use the Regression analysis model. Data collection procedures in this study use non-behavioral observation techniques, namely data collection by recording, studying, and reviewing secondary data in the form of financial statements and company company profile profiles 
obtained from the Indonesia Capital Market Directory for the period 2006 - 2010, as well as from downloading sites the official Indonesia Stock Exchange, namely; www.idx.co.id.

Table 1 - Population and Research Sample Manufacturing Industry Company on the Indonesia Stock Exchange for the period 2005-2011

\begin{tabular}{|l|c|}
\hline \multicolumn{1}{|c|}{ Information } & Total \\
\hline Total population & 169 \\
\hline Manufacturing industry companies that experienced delisting in the period 2005-2011 & $(42)$ \\
\hline $\begin{array}{l}\text { Non-consecutive manufacturing industry companies distributed cash } \\
\text { dividends for the period of 2005 - 2011. }\end{array}$ & $(116)$ \\
\hline Number of final samples & 11 \\
\hline Year of observation & 7 \\
\hline Number of observations & 77 \\
\hline
\end{tabular}

Source: ICMD 2006 - 2010, www.idx.co.id.

\section{RESULTS AND DISCUSSION}

The application of Multiple Linear Regression in this study is intended to be able to explain the magnitude of the effect of return on investment, earnings per share, operating cash flow, economic value added, and market value added to stock returns on manufacturing industry companies in the Indonesia Stock Exchange period 2005 - 2011. Results analysis of each variable can be seen in Table 2.

Table 2 - Regression Model Estimation Results

\begin{tabular}{|c|c|c|c|c|c|c|}
\hline \multirow{2}{*}{ Independent Variable } & \multirow{2}{*}{ Regression Coef. } & \multirow{2}{*}{$\mathrm{t}$ - count } & \multirow{2}{*}{ Sig. $t$} & \multirow{2}{*}{ Partial Correlation } & \multicolumn{2}{|c|}{ Collinearity statistics } \\
\hline & & & & & Tolerance & VIF \\
\hline Constanta & & 2,160 & 0,034 & & & \\
\hline $\mathrm{ROI}(\mathrm{X} 1)$ & $-0,037$ & $-0,293$ & 0,811 & $-0,026$ & 0,493 & 2,029 \\
\hline EPS (X2) & $-0,022$ & $-0,143$ & 0,887 & $-0,017$ & 0,489 & 2,045 \\
\hline Operation Cash Flow (X3) & $-0,178$ & $-3,053$ & 0,001 & $-0,384$ & 0,273 & 3,659 \\
\hline EVA (X4) & 0,790 & 3,956 & 0,000 & 0,425 & 0,288 & 3,467 \\
\hline MVA (X5) & $-0,128$ & $-1,084$ & 0,282 & $-0,128$ & 0,819 & 1,221 \\
\hline $\mathrm{R}$ & 0,429 & & & & & \\
\hline $\mathrm{R}^{2}$ & 0,184 & & & & & \\
\hline F count & 3,203 & & & & & \\
\hline F Significance & 0,012 & & & & & \\
\hline Durbin - Watson & 2,199 & & & & & \\
\hline
\end{tabular}

Source: Processed Data, 2019.

Based on the estimation results as shown in Table 2, the equation of the Multiple Linear Regression model is as follows:

$$
Y=-0,037 X 1-0.022 X 2-0,718 X 3+0,790 X 4-0,128 X 5
$$

The plus and minus signs on the Regression coefficient of each independent variable indicate the direction of influence of each independent variable $(X)$ on the dependent variable $(Y)$. Regression coefficient $\mathrm{X} 4$ plus $(+)$, this shows that, Economic value added has a positive influence on stock returns, while $\mathrm{X} 1, \mathrm{X} 2, \mathrm{X} 3$, and $\mathrm{X} 5$ are minus signs which indicate that, return on investment, earnings per share, operating cash flow, and market value added has a negative effect on stock returns.

Effect of Return On Investment on stock returns. Based on the results of analysed data, it can be seen that the return on investment does not have a statistically significant effect on stock returns, meaning that if the value of return on investment rises, the value of stock returns will fall. These results indicate that, the return value for the observed company stock will decrease if the value of return on investment rises, and vice versa. The results in this study are certainly very contradictory to the arguments of (Modigliani and Miller; in Brigham and Houston, 2006) which state that, the value of a company will depend only on 
the profits generated by the company's assets. This finding also contradicts some previous studies which concluded that there was a significant positive effect of return on investment or return on assets on stock returns (Sudiyatno and Suharmanto, 2011; Zuliarni, 2012; and Priatinah and Kusuma, 2012).

The insignificant effect of return on investment indicates that the implementation of company policies in managing assets to produce profits in manufacturing companies is not captured by investors as a signal. This is because the policy is a long-term company policy which certainly requires careful calculation, large capital, long term, and high risk. In particular, company assets, especially tangible assets, are certainly difficult to estimate by investors, because they are strongly influenced by investment opportunities in the future. Once the investment decision is wrong, it is very fatal for the issuer to return the capital that has already been embedded in the asset, therefore we need accurate calculation results regarding the return of the investment.

Another argument that leads to the insignificant influence of these two variables is that the higher the investment opportunity owned by the company, the higher will be external funds, especially debt if retained earnings are inadequate. Referring to the trade-off theory if the position of the capital structure is above the optimal capital structure target, then any additional debt will reduce the value of the company. Increasing the debt ratio will certainly have an impact on the profitability of the company, because some of the profits are used to pay interest on the loan. With greater interest costs, the company's net profit will decrease, so that shareholder rights to dividends are also reduced. The results of this study support research conducted by (Setiyorini, 2011; and Arista and Astohar, 2012) which concluded that, return on assets has no significant effect on stock returns.

Effect of Earning Per Share on stock returns. Based on the results of analysed data, it can be seen that earnings per share statistically does not have a significant effect on stock returns, meaning that if earnings per share go up, stock returns will fall. These results indicate that, the return value for the observed company stock will decrease if the value of earnings per share goes up, and vice versa.

The results of this study are not consistent with some previous studies, such as; Pradhono and Christiawan (2004), Dimitros et al. (2006), Amelia and Sulisyowati (2007), Seetharaman and Raj (2011), Nurfadillah (2011), Hatta and Dwiyanto (2012), Pratinah and Kusuma (2012), and Susetyo (2013) which stated that, increased earnings per share has a positive and significant effect on increasing stock returns. The insignificant effect of earnings per share indicates that, the orientation of investors in investing in shares in manufacturing companies is not an indicator of net income. Companies whose net income looks good may not necessarily have added value from their operational activities (Setiyorini, 2011), this is related to capital costs that have not been considered in obtaining net income after tax.

Earning per share shows the proportion of company profits recognized in each share. Thus, earning per share performance indicates a high dividend signal, but in practice the distribution of dividends to public companies in Indonesia is not determined on the value of earnings per share but will be determined through a General Meeting of Shareholders (GMS). Dividend payments are also a long-term company policy that will be linked to the ability to generate cash inflows to finance the dividends. This finding supports previous research conducted by Tiswiyanthi (2011), Setiyorini (2011), Arista and Astohar (2012), and Rahmadi (2013) who revealed that high and low earnings per share had no significant effect on stock returns.

Effect of Operating Cash Flow on stock returns. Based on the results of analysed data, it can be seen that operating cash flow has a statistically significant negative effect on stock returns, meaning that if operating cash flow rises, stock returns will fall. These results indicate that, the return value for the observed company stock will decrease if the value of operating cash flow goes up, and vice versa. The results obtained are also not consistent in some previous studies, including; Pradhono and Christiawan (2004), Setiyorini (2011), Pangemanan and Budiarso (2011), Qodriyah (2012), Rahmadi (2013), and Trisnawati and Wahidawati (2013) who said that, an increase in stock returns occurred as a result of the increasing value of current flows operating cash. 
The negative effect of operating cash flow on stock returns indicates that, manufacturing companies in the distribution of dividends support the residual dividend model. That is, the company will fund all investment opportunities that generate a positive net present value (NPV), try to keep the capital structure at a certain target, withhold profits to maintain the target capital structure, and if it is still left then the money is paid as dividends, or if the company decides to funding investment by issuing new shares will reduce retained earnings so that dividends paid can be more. The point is the amount of the dividend is determined last after considering the size of the investment, capital structure targets, profit targets, and decisions on the number of new shares to be issued.

According to Arifin (2007) making dividends as residuals is a rational strategy to maximize corporate value. The essence of growth for a corporation, one of which is the existence of investment opportunities that can provide benefits for the company. Investments that provide a positive net present value indicate that the investment is feasible to run. Companies that choose to take advantage of investment opportunities will use operating cash flow to fund it, so this condition will reduce the portion of dividends that can be paid to shareholders. This research supports a study conducted by Tiswiyanthi (2011), and Meyhi and Hartono (2012) which revealed a significant negative effect on operating cash flow on stock returns.

Effect of Economic Value Added on stock returns. Based on the results of the analysed data, it can be seen that statistically economic value added has a significant positive effect on stock returns, meaning that if economic value added rises, stock returns will also rise. These results indicate that, the observed company stock returns will rise if the economic value added increases, and vice versa.

Utomo (1999) said, the principle of EVA provides a good measurement system to assess a company's management performance and achievement, because economic value added performance is directly related to market value. EVA is said to be up to $50 \%$ better than earnings in explaining shareholder welfare (Steward, 1991), meaning economic value added is a more appropriate and accurate method for measuring wealth of stockholders than earning method. Performance appraisal with EVA causes management to think and act in accordance with the interests of shareholders, namely choosing investments that maximize the rate of return and minimize the level of capital costs, so that the value of the company can be maximized and create value for shareholders. Thus it can be interpreted that, the creation of performance with the EVA concept is assumed to carry more missions in aligning management objectives and the interests of shareholders, so as to minimize the potential for agency problems (agency cost).

Significant effect of economic value added on stock returns shows that, EVA has information content that is responded by market participants as a positive signal, in which the company managed to create value for the company owner. Value creation for company owners certainly impacts investors' trust and interest in the company's shares. The higher investor interest in company shares makes the stock price also higher. The higher stock prices will have an impact on increasing the value of the company. This research supports previous studies conducted by (Lehn et al., 1996; in Iriana, 2003), Worthington and West (2004), Idamiharti (2010), and Turangan and Wijaya (2015) which states that, economic value added influences significant positive on stock prices or returns.

Effect of Market Value Added on stock returns. Based on the results, it can be seen that statistically added market value has no significant effect on stock returns, meaning that if market value added rises, stock returns will fall. These results indicate that, the observed company stock returns will decrease if the value of the market value added goes up, and vice versa.

The results obtained in this study contradict the previous empirical evidence published by Sasongko et al. (2013), and Turangan and Wijaya (2015) which stated that there was a positive and significant influence of market value added on stock returns or prices. The insignificant results indicate that, investors who want to invest capital in manufacturing companies do not make MVA performance as the main basic valuation in a stock investment strategy or it can be said that investors do not base their sell-buy decisions on market value 
indicators added. The value of a company is the total market value of the debt and the market value of the stock. The debt market value is relatively constant, while the stock market value is relatively fluctuating. This is because the stock market value is very sensitive to changes that occur both changes due to external factors and due to internal factors.

The development of stock prices in manufacturing companies that were sampled mostly showed fluctuations (appendix 8). Public companies whose share prices fluctuate very high indicate that the company is also at high risk (Sudiyatno, 2010). Investors must be very careful in choosing investments in the company, meaning that investors will demand a high risk premium, so that the expected return is also high to cover these risks both through dividend yields and capital gains that are expected to be obtained. This finding supports previous research by Heriani (2011), and Rahayu and Aisjah (2013) which states that, market value added has no significant effect on stock returns.

\section{CONCLUSION}

Based on the results of data analysis and the discussion of the previous chapter, this study produced several conclusions that can be described, as follows Return on investment has no significant effect on stock returns, this shows that the higher the value of ROI created by companies does not have a significant effect on stock returns shareholders will get. Earning per share has no significant effect on stock returns, this implies that the higher the value of earnings per share causes the low stock returns to be obtained by shareholders. Operating cash flow has a significant negative effect on stock returns, this indicates that the amount of operating cash flow owned by the company causes low stock returns to be distributed to shareholders. Economic value added has a significant positive effect on stock returns, this indicates that EVA performance has information content that is responded to by investors as a positive signal, where the company has succeeded in maximizing value for company owners. Maximizing value for company owners is certainly in line with maximizing company value. Market value added has no significant effect on stock returns, this shows that the higher market value created by the company does not have a significant effect on stock returns that will be received by shareholders.

Based on the description of the conclusions, the suggestions in this study include for company managers, the results of this study are expected to be used as input and consideration so that performance measurement does not only focus on financial ratios but must also take into account the cost of capital, so that the real capabilities of the company are visible, while that for investors EVA performance can be used as a systematic measure in helping investment decision making. This is because EVA performance is related to value creation for shareholders. For further research, it is expected to be able to add other variables that are thought to influence stock returns, this is because the magnitude of the coefficient of determination in the Regression model $\left(R^{2}\right)$ is 0.184 which means only $18.4 \%$ changes or variations in stock returns that can be explained by the model, whereas the remaining $81.6 \%$ comes from other variables not included in the research model. Likewise, the addition of samples and research periods will support the process of data analysis, so that research results can be more generalized.

\section{REFERENCES}

1. Ang, R. 1997. Buku Pintar Pasar Modal Indonesia. Jakarta: Mediasoft.

2. Anonim. 2012. "Surviving Crisis a Quest for Prosperity" Indonesia's Economic Review 2004 - 2012. Indonesia Finance Today.

3. Anonim. 2006. Indonesia Capital Market Directory 2006. Jakarta: ECFIN.

4. 2007. Indonesia Capital Market Directory 2007. Jakarta: ECFIN.

5. 2008. Indonesia Capital Market Directory 2008. Jakarta: ECFIN.

6. 2009. Indonesia Capital Market Directory 2009. Jakarta: ECFIN.

7. 2010. Indonesia Capital Market Directory 2010. Jakarta: ECFIN. 
8. Arista, D. and Astohar. 2012 Analisis Faktor - Faktor Yang Mempengaruhi Return Saham (Kasus pada perusahaan manufaktur yang go public di BEI periode tahun 2005 2009). Jurnal Ilmu Manajemen and Akuntansi Terapan, Vol. 3, No.1.

9. Almilia, L.S. and Sulistyowati, D. 2007. Analisa Terhadap Relevansi Nilai Laba, Arus Kas Opeasi and Nilai Buku Ekuitas Pada Periode Di Sekitas Krisis Keuangan Pada Perusahaan Manufaktur Di BEJ. Proceeding Seminar Nasional. Inovasi dalam Menghadapi Perubahan Lingkungan Bisnis. FE Universitas Trisakti Jakarta, 9 Juni 2007.

10. Brigham, F. E. and Houston, F. J. 2006. Dasar - dasar Manajemen Keuangan. Buku 1. Edisi 10. Jakarta: Salemba Empat.

11. Benardi, J. K. 2010. Pengaruh Cash Flow Terhadap Leverage and Investasi Serta Dampaknya Terhadap Nilai Perusahaan. Jurnal Ekonomi and Kewirausahaan, Vol. 10, No. 2, $93-108$.

12. Dimitros, 2006. The Introduction of Economic Value Added (EVA) in The Greek Corporate Sector. The Southeeuropean Review of Business and Accounting. Vol.4. No.2.

13. Fahmi, I. 2013. Glosarium Ilmu Manajemen \& Akuntansi. Bandung: Alfabeta.

14. Hartono, J. 2008. Teori Portofolio and Analisi Investasi. Edisi 5. Yogyakarta: Bpfe

15. Heriani, A. 2011. Analisis Pengaruh ROA, EVA, MVA, and Resiko Pasar Terhadap Return Saham Perusahaan Otomotif Yang Listing Di Bursa Efek Indonesia. Jurnal IImu Ekonomi.

16. Hatta, A.J. and Dwiyanto, B.S. 2012. The Company Fundamental Factor and Systematic Risk In Increasing Stock Price. Journal of Economics, Business, and Accountancy. Vol. 15. No. 2. pp. $245-256$.

17. Harjito, D. A. and Rangga, A. 2009. Analisis Pengaruh Kinerja Keuangan and Return Saham di Bursa Efek Jakarta. Fenomena. Jurnal Ekonomi Vol. 7. No. 1, Hal: 13 - 21.

18. Idamiharti. 2010. Pengaruh Economic Value Added Terhadap Created Shareholder Value. Jurnal Akuntansi and Manajemen. Vol. 5. No.1. Hal: 21- 31.

19. Iriana, P. 2003. Perspektif Shareholder Value - Creation Dalam Pengukuran Kinerja Dengan EVA. Jurnal Keuangan Kompak. No.8, Mei - Agustus, Hal. 224 - 239.

20. Meythi, and Hartono, S. 2012. Pengaruh Informasi Laba and Arus Kas Terhadap Harga Saham. Jurnal Ilmiah Akuntansi, No. 7.

21. Nurfadillah, M. 2011. Analisis Pengaruh Earning Per Share, Debt To Equity Ratio and Return On Equity Terhadap Harga Saham PT Unilever Indonesia Tbk. Jurnal Manajemen and Akuntansi, Vol.12, No. 1.

22. Nany, M. 2013. Analisis Kemampuan Prediksi Arus Kas Operasi (Studi Pada Bursa Efek Indonesia). Jurnal Dinamika Akuntansi, Vol. 5, No. 1, Maret 2013.

23. Priatinah, D. and Kusuma, P.A. 2012. Pengaruh Return On Investment (ROI), Earning Per Share (EPS), and Dividen Per Share (DPS) Terhadap Harga Saham Perusahaan Pertambangan Yang Terdaftar Di Bursa Efek Indonesia (BEI) Periode 2008 - 2010. Jurnal Nominal, Vol. 1, No. 1.

24. Pradhono. and Christiawan. Y. J. 2004. Pengaruh Economic Value Added, Residual Income, Earning, and Arus Kas Operasi Terhadap Return Yang Diterima Oleh Pemegang Saham (Studi pada perusahaan manufaktur yang terdaftar di Bursa Efek Jakarta), Jurnal Akuntansi and Keuangan 6. pp. 140-166.

25. Pangemanan, S., Budiarso, N. 2011. Pengaruh Interaksi Laba and Arus Kas Operasi Terhadap Return Saham Pada Perusahaan Manufaktur Di Bursa Efek Indonesia. Jurnal Riset Akuntansi and Auditing, Vol. 2, No.2, Desember 2011.

26. Puspitasari, R., Analisis Arus Kas Operasi Dalam Mencapai Nilai Perusahaan Yang Optimal. Studi Kasus Pada PT Semen Gresik (Persero) Tbk. Jurnal Ilmiah Kesatuan Nomor 2. Volume 12. Oktober 2010.

27. Qodriyah, R. D. L. 2012. Laba Atau Arus Kas Sebagai Parameter Kinerja Perusahaan Berdasarkan Siklus Hidup Perusahaan (Studi relevansi nilai). Jurnal Akuntansi and Ekonomi Bisnis. Vol. 1 No. 1.

28. Rahayu, U. T. and Aisjah, S. 2012. Pengaruh Economic Value Added and Market Value Added Terhadap Return Saham. (online), (http:// Jimfeb.ub.ac.id/index. php/jimfeb/article). 
29. Rahmadi, Y. D. 2013. Pengaruh Earning Per Share, Arus Kas Operasi, Economic Value Added, and Market Value Added Terhadap Return Saham (Studi pada perusahaan manufaktur yang terdaftar pada BEI) (on line), (http: //ejournal.unp. ac. id/students/index.php/akt).

30. Sartono, R. A. 2008. Manajemen Keuangan Teori and Aplikasi. Edisi 4. Yogyakarta.

31. Stewart, G.B III. 1991. The Quest for Value: The EVA Management Guide. New York: Harper Business.

32. Susetyo, A. T. 2013. Pengaruh Nilai Tambah Ekonomis, Earning Per Share and Price Earning Ratio Terhadap Pengembalian Saham. Jurnal IImu Manajemen, Vol.1, No. 1.

33. Sudiyatno, B. 2011. Kinerja Keuangan Konvensional, Economic Value Added, and Return Saham. Jurnal Dinamika Manajemen. Vol. 2 No. 2. pp: 153-161.

34. Setiyorini, P.I. 2011. Pengaruh Perbandingan Economic Value Added and Rasio Profitabilitas Terhadap Return Saham. Jurnal Ekonomi and Bisnis. No.3. Hal. 191 - 208.

35. Sudiyatno, B. 2010. Peran Kinerja Perusahaan Dalam Menentukan Pengaruh Faktor Fundamental Makro Ekonomi, Risiko Sistematis, and Kebijakan Perusahaan Terhadap Nilai Perusahaan (Studi Empirik Pada Perusahaan Manufaktur Di Bursa Efek Indonesia), Disertasi, Program Doktor IImu Ekonomi Kekhususan Manajemen, Program Pascasarjana Universitas Diponegoro, Semarang. Tidak dipublikasikan.

36. Seetharaman, A and Raj, JR. 2011. An Empirical Study on the Impact of Earnings per Share on Stock Price of a Listed Bank in Malaysia. The International Journal of Applied Economics and Finance. 5 (2), pp. 114 - 126.

37. Sukartha, I. M. 2007. Meningkatkan Manfaat Informasi Akuntansi Akibat Keterbatasan Laporan Keuangan Untuk Pembuatan Keputusan Investasi. AUDI Jurnal Akuntansi \& Bisnis, Vol. 2, No. 1, Januari 2007.

38. Sasongko, H. Kurniadi, A. and Achsani, N. A. (2013). Kinerja Keuangan Berbasis Penciptaan Nilai, Faktor Makro Ekonomi and Pengaruhnya Terhadap Return Saham Sektor Pertanian. Jurnal Akuntansi and Keuangan Vol.15, No. 2, November 2013.

39. Sari, M. M. R, 2007. Perbedaan Reaksi Pasar Sebelum and Selama Krisis Moneter Atas Pengungkapan Laba Pada Perusahaan Yang Terdaftar Di Bursa Efek Jakarta. Jurnal Akuntansi and Bisnis Vol 2 No. 1.

40. Sunardi. H. 2010. Pengaruh Penilaian Kinerja Dengan ROI and EVA Terhadap Return Saham Pada Perusahaan Yang Tergabung Dalam Indeks LQ 45 Di Bursa Efek Indonesia. Jurnal Akuntansi, Vol. 2, No. 1 Mei 2010.

41. Tiswiyanti. W. 2011. Pengaruh Economic Value Added (EVA), Residual Income, Earning and Arus Kas Operasi Terhadap Return Yang Diterima Pemegang Saham Pada Perusahaan LQ45 Tahun 2008 - 2009. Jurnal Penelitian Universitas Jambi Seri Humaniora. Vol.13.No.1. Hal. 41 - 46.

42. Tandelilin, E. 2001. Analisis Investasi and Manajemen Portofolio. Edisi Pertama. Yogyakarta: YKPN.

43. Trisnawati, W. and Wahidahwati. 2013. Pengaruh Arus Kas Operasi, Investasi and Pendanaan serta Laba bersih terhadap Return Saham. Jurnal IImu and Riset Akuntansi. Vol.1, No.1, Januari 2013.

44. Turangan. J. A. 2015. Ukrida National Conference - Belitung, 3-4 September 2015.

45. Utomo, L. L. 1999. Economic Value Added Sebagai Ukuran Keberhasilan Kinerja Manajemen Perusahaan, Jurnal Akuntansi and Keuangan, Vol.1, No.1.

46. Worthington, A.C. and West, T. 2004. Australian Evidence Concerning the Information Contenc of Economic Value Added, Australian Journal of Management 29. pp. 201-223.

47. Wiagustini, N.L.P. 2014. Manajemen Keuangan. Udayana University Press.

48. Wira, Desmond. 2011. Analisis Fundamental Saham. Exceed.

49. Zuliarni, S. 2012. Pengaruh Kinerja Keuangan Terhadap Harga Saham Pada Perusahaan Mining and Mining Service Di Bursa Efek Indonesia (BEl). (on line) (http://ejournal.unri.ac.id/index.php/JAB/article/view/90).

50. Electronic Source: www.idx.co.id 